\title{
Fiscal Decentralization and Disparity of Access to Primary Education in Indonesia
}

\author{
Shinta Doriza ${ }^{1}$, Deniey Adi Purwanto ${ }^{2}$, Ernita Maulida ${ }^{1}$ \\ ${ }^{1}$ Universitas Negeri Jakarta, \\ Jl. Rawamangun Muka, Jakarta, Indonesia, Phone: +62-21-4715094 \\ E-mail address: shintadoriza@unj.ac.id
}

${ }^{2}$ Institut Pertanian Bogor,

Jl. Raya Darmaga Darmaga Bogor 16680, Jawa Barat, Indonesia, Phone: +62-251-8622642

\begin{abstract}
In education, one crusial issue of development is the disparity of primary education access. Using 440 regions database from 2005-2009, this study is aim to analize the impact of fiscal decentralization in reducing the enrolement of primary education in Indonesia. Three factors were included, i.e fiscal decentralization, socioeconomic factors and regional characteristics. The result of panel data estimation using fixed-effect approach on this study is that DAK for Education, DAK Non Education, and PAD have significant impact in reducing education acess disparity along with poverty and regional characteristic such as Java-non Java regions. For education level, another variable was also found significant including education of the society and regional characteristic such as proliferated-non proliferated regions. In general there is a facts and proves that fiscal decentralization improve education access equality, but several effort need to done to optimalize the equalization of primary education access in Indonesia.
\end{abstract}

Keywords: decentralization, primary education access, education access equality, panel data JEL Classification Codes: I20, R50, I24, C23

\section{Desentralisasi Fiskal dan Disparitas Akses Pendidikan Dasar di Indonesia}

\begin{abstract}
Abstrak
Dalam pendidikan, satu isu krusial pembangunan adalah kesenjangan akses pendidikan dasar. Penelitian ini menggunakan data 440 daerah dari 2005-2009. Penelitian ini bertujuan untuk menganalisa dampak desentralisasi fiskal dalam mengurangi kesenjangan pendidikan dasar di Indonesia. Ketiga faktor tersebut termasuk di dalamnya, seperti desentralisasi fiskal, faktor sosial ekonomi dan karakteristik daerah. Hasil estimasi data panel menggunakan pendekatan fixed-efek bahwa DAK untuk Pendidikan, Pendidikan DAK dan non pendidikan, dan PAD memiliki dampak yang signifikan dalam mengurangi disparitas akses pendidikan bersama dengan kemiskinan dan karakteristik daerah seperti Jawa dan luar Jawa. Untuk tingkat pendidikan, variabel lain juga ditemukan signifikan termasuk pendidikan masyarakat dan karakteristik daerah berkembang dan non berkembang. Secara umum ada fakta dan membuktikan bahwa desentralisasi fiskal meningkatkan akses pendidikan, tapi perlu beberapa upaya dilakukan untuk mengoptimalkan pemerataan akses pendidikan dasar di Indonesia.
\end{abstract}

Kata kunci: desentralisasil, akses pendidikan dasar, pemerataan akses pendidikan, data panel Kode Klasifikasi JEL: I20, R50, I24, C23 


\section{Pendahuluan}

Desentralisasi fiskal merupakan perwujudan dari "money follow function" dari implementasi kebijakan otonomi daerah di Indonesia. Semangat yang mendasari otonomi daerah dan desentralisasi fiskal adalah untuk lebih mengoptimalkan pelaksanaan pembangunan dan hasil-hasilnya. Kebijakan pembangunan yang sentralistis pada era sebelumnya telah menimbulkan berbagai permasalahan dalam pembangunan termasuk salah satunya kesenjangan pembangunan antardaerah. Oleh karena itu orientasi lainnya dari desentralisasi fiskal adalah mengurangi kesenjangan pembangunan antardaerah (Brodjonegoro, 2003).

Di sisi lain, undang-undang mengamanahkan fokus anggaran pemerintah yang lebih besar pada bidang pendidikan untuk dapat lebih mengoptimalkan pembangunan pendidikan serta yang lebih penting lagi adalah meningkatkan akses pendidikan bagi seluruh masyarakat. Masalah akses pendidikan menjadi salah satu prioritas pemerintah. Dalam Rencana Pembangunan Pendidikan 2005-2009, pemerintah mentargetkan penurunan disparitas akses pendidikan tingkat SD dan SMP melalui penurunan disparitas Angka Partisipasi Kasar (APK) SD dan SMP antara kabupaten/kota.

Secara umum sepanjang 2004-2009 disparitas akses pendidikan dasar semakin menurun. Untuk tingkat SD, disparitas APK menurun dari 2,49 persen di tahun 2004 menjadi 2,40 persen di tahun 2009. Sementara untuk SMP, APK menurun dari 25,1 persen di tahun 2004 menjadi 23 persen di tahun 2009. Namun jika melihat capaian dari penurunan APK SD dan SMP yang ditargetkan, nampaknya beberapa hal masih menjadi kendala untuk dapat lebih mengoptimalkan pemerataan akses pendidikan dasar. Disparitas APK SD untuk tahun 2009 saja ditargetkan sebesar 2,30 persen dan 19 persen untuk disparitas APK SMP (Kemdiknas, 2009). Terkait dengan desentralisasi fiskal, berbagai instrumen yang telah dijalankan seharusnya memainkan peranan dalam meningkatkan pemerataan akses pendidikan dasar.

Desentralisasi Fiskal dan Disparitas

Pembangunan. Otonomi daerah dan desentralisasi fiskal bertujuan untuk lebih mengoptimalkan pelaksanaan pembangunan dan hasil-hasil dengan lebih mendekatkan layanan pemerintah kepada masyarakat sekaligus mengurangi kesejangan pembangunan antardaerah. Desentralisasi fiskal merupakan salah satu mekanisme transfer dana dari APBN dalam kaitan dengan kebijakan keuangan negara yaitu untuk mewujudkan ketahanan fiskal yang berkelanjutan (fiscal sustainability) dan memberikan stimulus terhadap aktivitas perekonomian masyarakat (Elmi, 2002). Dengan desentralisasi fiskal diharapkan akan tercipta pemerataan kemampuan keuangan antar daerah yang untuk membiayai kewenangan urusan pemerintahan yang diserahkan kepada daerah.

Sejalan tujuan-tujuan desentralisasi fiskal tersebut, transfer keuangan pemerintah kepada pemerintah pusat dilaksanakan melalui beberapa instrumen melalui sisi belanja daerah pada keuangan pemerintah pusat dan penerimaan pada keuangan pemerintah daerah. Pertama adalah melalui instrumen yang secara konseptual disebut sebagai fiscal balancing instrument. Dalam prakteknya di Indonesia diimplementasikan melalui dana bagi hasil (DBH) baik pajak maupun non pajak. Kedua melalui instrumen yang berdasarkan ketentuan dan spesifikasi teknisnya dapat dikatakan sebagai less conditioned-type transfer instrument. Implementasi instrumen jenis ini dilaksanakan melalui Dana Alokasi Umum (DAU). Dana ini dialokasikan berdasarkan kapasitas fiskal masing-masing daerah sehingga diharapkan dapat mengimbangi disparitas kemampuan daerah dalam membiayai pembangunan. Ketiga, terdapat pula instrumen desentralisasi fiskal yang dapat digolongkan sebagai conditioned-type transfer instrument yaitu Dana Alokasi Khusus (DAK). DAK dialokasikan kepada daerah dan sektor-sektor tertentu berdasarkan prio- 
ritas dan arah pembangunan nasional. Yang tidak kalah pentingnya adalah instrumen Pendapatan Asli Daerah (PAD) yang sangat menentukan kapasitas fiskal suatu daerah untuk membiayai pembangunan di daerahnya masing-masing.

DBH, DAU dan DAK merupakan instrumen-instrumen desentralisasi fiskal sementara PAD merupakan instrumen keuangan pemerintah daerah yang erat kaitannya dengan instrumen desentralisasi fiskal yang ada. Instrumen-instrumen tersebut mendukung pelaksanaan pembangunan di daerah baik secara langsung yang dialokasikan kepada sektor atau bidang tertentu (misalnya Pendidikan) maupun secara tidak langsung melalui peningkatan kondisi sosial ekonomi masyarakat. Dengan peningkatan kondisi sosial ekonomi masyarakat inilah kesenjangan atau disparitas pembangunan antar daerah dapat diturunkan termasuk disparitas akses terhadap layanan pendidikan dasar.

Input dan Output Pembangunan Pendidikan. Dalam analisis pembangunan pendidikan dapat digunakan pendekatan teori produksi dasar sebagaimana dikemukakan dalam fungsi produksi Cobb Douglass dimana:

$Y=A L^{\alpha} K^{\beta}$

Dalam bentuk linier dalam diformulasikan sebagai berikut:

$\ln (Y)=\ln (A)+\alpha \ln (L)+\beta \ln (L)$

$Y$ adalah kuantitas produksi, L input tenaga kerja, $\mathrm{K}$ input modal dan $\mathrm{A}$ adalah representasi faktor produktivitas total (Total Factor Productivity). a dan $\beta$ adalah koefisien elastisitas output dari tenaga kerja dan modal. Asumsinya koefisien elastisitas ini adalah constants return to scale yang ditentukan oleh tingkat teknologi yang tersedia $(a+$ $\beta=1)$.

Dalam Pendekatan teori produksi untuk pendidikan (Education Production Function/ $E P F)$, sekolah diandaikan sebagai suatu unit produksi pada sisi penawaran. Berbeda dengan unit produksi pada model ekonomi umumnya, sekolah diasumsikan sebagai unit yang tidak memaksimalkan keuntungan (non profit-maximizing firms) di mana pada umumnya adalah berstatus negeri atau swasta (Boissiere, 2004). Pendekatan EPF ini dapat menjelaskan efektifitas sekolah sehingga dapat menjawab apa yang dapat dilakukan terhadap input sehingga dapat meningkatkan output (dalam hal ini pelayanan pendidikan). Murillo, et. al. (2001) menguraikan beberapa faktor yang mempengaruhi siswa/lulusan dalam pendekatan EPF, di antaranya:

(1) Faktor personal seperti gender dan suku. (2) Faktor keluarga seperti tingkat sosial ekonomi, jumlah anggota keluarga dan tingkat pendidikan orang tua siswa. (3) Faktor yang berhubungan dengan tempat tinggal. (4) Faktor sekolah dan guru.

Berdasarkan fungsi produksi dasar, Glewwe (2002) merumuskan satu fungsi produksi untuk pendidikan (EPF) yang inklusif dengan formulasi sebagai berikut:

$$
\begin{aligned}
H= & c+\alpha S+\beta_{1} A_{1}+\beta_{2} A_{2}+\ldots+\beta_{n} A_{n}+\delta_{1} Q_{1}+ \\
& \delta_{2} Q_{2}+\ldots+\delta_{m} Q_{m}+u
\end{aligned}
$$

$\mathrm{H}$ adalah modal manusia yang menggunakan ukuran tingkat pengetahuan, $\mathrm{S}$ adalah sekolah atau tahun lama sekolah. A merepresentasikan kemampuan dan kapasitas belajar siswa dan $Q_{i}$ adalah faktor kualitas sekolah seperti besar kelas, kualifikasi guru dan sebagainya.

Dampak Desentralisasi Fiskal terhadap Pendidikan. Ketika diskusi tentang aspek-aspek pembangunan terus berkembang, faktor-faktor lainnya turut dipertimbangkan. Faguet \& Sanchez (2007) menggunakan model yang serupa dengan mempertimbangkan dampak desentralisasi terhadap output pendidikan. Formulasi model yang dijabarkan adalah sebagai berikut:

$$
\begin{aligned}
\Delta S_{m t}= & \alpha+\zeta D_{m t}+\beta R_{m t}+\gamma P_{m t}+ \\
& \delta C_{m t}+\varepsilon_{m t}
\end{aligned}
$$

di mana $\Delta S$ adalah peningkatan angka partisipasi sekolah, D adalah vektor yang menjelaskan karakteriktik daerah, $\mathrm{R}$ adalah vektor 
yang mengukur ketersediaan sumber daya (faktor penawaran), P adalah vektor yang mengukur partisipasi politik dan kerjasama. Kemudian $\mathrm{C}$ adalah vektor yang menjelaskan kontrol faktor-faktor sosial ekonomi dan geografis sedangkan $\mathrm{m}$ adalah vektor yang menjelaskan ukuran-ukuran desentralisasi fiskal merepresentasikan dimensi daerah sementara $t$ adalah dimensi waktu untuk semua vektor.

Oleh karena itu penelitian ini dilaksanakan untuk mengkaji sejauhmana dampak desentralisasi fiskal terhadap pengurangan disparitas akses pendidikan dasar. Untuk memperoleh gambaran yang lebih komprehensif, ditambahkan pula beberapa faktor yang secara teoritis dan empiris turut mempengaruhi disparitas akses pendidikan dasar. Dalam hal ini adalah faktor-faktor sosial ekonomi masyarakat dan karakteristik daerah. Penelitian ini diharapkan dapat menjawab berbagai permasalahan dalam mengoptimalkan desentralisasi fiskal dalam peningkatan pemerataan akses pendidikan dasar dan sekaligus dapat berkontribusi terhadap penyusunan kebijakan dan penyelengaraan pendidikan dasar dan pengelolaan keuangan pemerintah.

\section{Metode Penelitian}

Data yang digunakan dalam studi ini adalah data sekunder bersumber dari Kementerian Pendidikan Nasional, Bappenas, Kementerian Keuangan dan BPS. Data dasar yang digunakan adalah panel data 440 kabupaten/kota di Indonesia sepanjang tahun 2005-2009. Sementara itu, model dasar yang digunakan dalam penelitian ini adalah model panel data analisis. Pengestimasian terhadap model data tersebut hasilnya diharapkan memperoleh konstanta intercept yang berbeda-beda untuk masing-masing kabupaten/kota di masingmasing tahun (Greene, 1997). Adapun spesifikasi model penelitian sebagai berikut:

$$
A S_{i, t}=\alpha_{i}+\gamma F D+\delta S_{i, t}+\lambda D_{i, t}+\varepsilon_{i, t}
$$

AS adalah disparitas akses pendidikan SD di tiap daerah. Untuk memperoleh cakupan analisis yang lebih luas, dalam penelitian ini digunakan disparitas APK SD dan SMP. AS merupakan variabel tidak bebas dalam model di atas. Sementara itu beberapa variabel bebas digunakan untuk menduga variabel tak bebas yang dikelompokkan dalam faktor-faktor. (FD) adalah faktor desentralisasi fiskal dimana di dalamnya terdapat beberapa indikator seperti DAU, DAK Pendidikan, DAK Non Pendidikan dan PAD untuk melihat bagaimana dampak masing-masing instrumen fiskal tersebut terhadap disparitas akses pendidikan SD.

Berikutnya adalah faktor latar belakang sosial ekonomi masyarakat (S). Beberapa studi terdahulu menekankan peranan latar belakang sosial ekonomi masyarakat terhadap kemauan dan kemampuan untuk mengakses pendidikan dasar. Beberapa variabel digunakan seperti pendapatan per kapita masyarakat, tingkat melek huruf dan tingkat kemiskinan. Tidak kalah penting adalah faktor karakteristik daerah (D) dimana variabel-variabel karakteristik daerah seperti kabupaten/kota, daerah pemekaran atau bukan daerah pemekaran serta Pulau Jawa atau bukan Pulau Jawa diduga juga mempunyai peranan yang signifikan terhadap disparitas akses pendidikan dasar. Seperti layaknya analisis data panel, (i) merupakan representasi provinsi yang ada dan $(t)$ merupakan periode atau tahun dari data yang digunakan.

Spesifikasi model di atas diestimasi dengan menggunakan metode analisis data panel dengan pendekatan fixed-effect (Baltagi, 2001) sehingga diperoleh gambaran bahwa koefisien masing-masing provinsi. Model dasar di atas diestimasi pada 2 kelompok data panel, yaitu data panel tingkat SD dan tingkat SMP dimana masing-masing diujicobakan dalam 6 spesifikasi yang berbeda. Dari 6 estimasi tersebut, dipilih 3 estimasi model yang cukup representatif baik secara statistik maupun substantif. Untuk memperoleh model ketiga ini digunakan pendekatan 
omitting variables (Hsiao, 2003) hingga didapat komposisi variabel bebas yang cukup robus.

\section{Hasil dan Pembahasan}

Hasil estimasi data panel yang dilakukan, terpilih 3 model umum yang cukup representatif untuk masing-masing tingkatan disparitas yang diuji, yaitu tingkat SD dan SMP. Secara umum model pertama adalah model dengan variabel bebas yang komprehensif termasuk di antaranya variabel-variabel dummy yang merepresentasikan karakteristik daerah. Model kedua adalah model yang mencoba menjelaskan bagaimana keragaan masing-masing provinsi terhadap penurunan disparitas akses pendidikan SD dan SMP di daerahnya masing-masing. Untuk mendapatkan hal ini digunakan pendekatan Cross Section Fixed-Effects serta tidak digunakannya variabel dummy dalam estimasi. Sementara untuk model ketiga, dapat dikatakan model cukup baik secara statistik maupun secara substantif (robust). Untuk memperoleh model ketiga ini digunakan pendekatan omitting variables hingga didapat komposisi variabel independent yang cukup robust.

Secara umum dapat dikatakan bahwa DAU kurang memberikan dampak terhadap disparitas akses pendidikan. Namun demikian hasil estimasi juga menunjukkan arah yang negatif antara DAU dan disparitas akses pendidikan. Dengan kata lain, terdapat kecenderungan bahwa semakin besar DAU semakin kecil disparitas akses pendidikan khususnya untuk tingkat SD. Hasil estimasi yang tidak signifikan menunjukkan bahwa DAU belum secara efektif berdampak terhadap penurunan disparitas akses pendidikan. Hal ini mengingat bahwa dari total alokasi DAU, berkisar 60 persen diantaranya termasuk gaji PNS, baik di bidang pendidikan maupun PNS lainnya secara umum. Terkait dengan tenaga pendidikan, dapat ditambahkan pula bahwa masih cukup banyak guru baik sekolah dasar maupun menengah yang bukan PNS. Berdasarkan data yang ada guru non PNS berkisar 30 persen dari total guru pada pendidikan SD dan SMP.

Berikutnya adalah DAK yang dalam analisis ini dipisahkan antara DAK bidang Pendidikan dengan Non Pendidikan. Jika DAU lebih bersifat Block Grant, maka DAK lebih bersifat Conditional Grant. Terkait dengan otonomi daerah dan desentralisasi, tidak banyak ruang bagi daerah untuk mengatur alokasi DAK karena setiap tahun peruntukkannya ditetapkan pemerintah pusat baik dari sisi kebijakan maupun dari sisi spesifikasi teknis. Menurut Nainggolan (2010) kriteria kelayakan kabupaten/kota yang lebih miskin.

Hasil estimasi memperlihatkan bahwa untuk DAK Pendidikan lebih berdampak nyata pada upaya pemerataan akses pendidikan di tingkat SMP. Hal ini dapat dijelaskan karena alokasi DAK Pendidikan banyak difokuskan pada perbaikan dan pembangunan fisik ruang kelas dan sekolah. Dengan demikian, pemerintah pusat kembali harus menginjeksi dana langsung ke kabupaten lewat DAK pendidikan yang ditujukan untuk rehabilitasi gedungan sekolah (Nainggolan, 2010).

Perbedaan alokasi DAK pendidikan antara SD dan SMP terdapat pada fokus pembangunan fisik yang direalisasikan kemudian. Seperti, lebih pada prioritas kondisi sekolah yang ada dan keterbatasan masing-masing daerah, atau sudah mencakup aspek pemerataan juga. Sementara itu, dari hasil estimasi juga terbukti bahwa DAK non pendidikan kurang sejalan dengan penurunan disparitas akses pendidikan.

Di sisi yang lain, PAD dapat dikatakan tidak berkaitan langsung terhadap desentralisasi fiskal. Namun selain menjadi salah satu faktor penentu bagi dana-dana perimbangan, PAD juga menentukan seberapa besar kemampuan daerah untuk mengoptimalkan pembangunan di daerahnya di luar danadana perimbangan. Dengan kata lain, prioritas pembangunan daerah akan lebih baik pencapaian jika didukung sumber penerimaan daerah yang otonom yaitu PAD. 
Dalam hal ini bisa jadi suatu daerah memprioritas pembangunan pada pendidikan SD dan SMP mendukung program pemerintah nasional baik sebagai teknis maupun finansial. Namun dari hasil estimasi yang ada, PAD berdampak siginifikan terhadap disparitas pendidikan tingkat SD saja. Inipun dengan arah yang positif dimana PAD yang lebih besar justru pada daerah-daerah yang disparitas akses pendidikannya relatif lebih besar pula. Dengan kata lain, hal ini menjadi satu indikasi bahwa tidak jarang daerah dengan kemampuan PAD yang relatif lebih besar dibandingkan daerah lain, kurang memfokuskan pembangunan pada bidang pendidikan paling tidak diluar program dan pembiayaan yang sudah dilaksanakan pemerintah pusat.

Sementara itu, tingkat pendidikan masyarakat diharapkan memberikan dampak yang positif terhadap akses pendidikan anak usia sekolah. Pada tingkat SD, akses pendidikan tidak lagi menjadi pembeda bagi keluarga dengan tingkat pendidikan yang lebih tinggi atau tidak. Atau dengan kata lain akses pendidikan dasar telah menjadi prioritas atau paling tidak perhatian keluarga secara umum di Indonesia. Pada tingkat

Tabel 1. Hasil Estimasi Model Disparitas Akses Pendidikan SD dan SMP

\begin{tabular}{|c|c|c|c|c|c|c|}
\hline \multirow{2}{*}{ Variabel Bebas } & \multicolumn{3}{|c|}{ Disparitas APK SD } & \multicolumn{3}{|c|}{ Disparitas APK SMP } \\
\hline & Model 1 & Model 2 & Model 3 & Model 1 & Model 2 & Model 3 \\
\hline \multicolumn{7}{|l|}{ Desentralisasi Fiskal } \\
\hline \multirow{2}{*}{$\overline{\text { PADCAP }}$} & $0,014^{*}$ & $0,026^{* * *}$ & $0,016^{* *}$ & $-0,009$ & $0,007^{* * *}$ & - \\
\hline & $(0,008)$ & $(0,009)$ & $(0,007)$ & $(0,006)$ & $(0,001)$ & \\
\hline \multirow[t]{2}{*}{ DAUCAP } & $-0,003$ & $-0,006$ & $-0,002$ & 0,002 & $-0,001$ & 0,001 \\
\hline & $(0,003)$ & $(0,004)$ & $(0,002)$ & $(0,001)$ & $(0,001)$ & $(0,001)$ \\
\hline \multirow[t]{2}{*}{ DAKPCAP } & 0,029 & $0,318^{* *}$ & - & $-0,080^{*}$ & 0,006 & $-0,065^{*}$ \\
\hline & $(0,094)$ & $(0,146)$ & & $(0,045)$ & $(0,040)$ & $(0,039)$ \\
\hline \multirow[t]{2}{*}{ DAKNPCAP } & 0,031 & $-0,046$ & $0,033^{*}$ & $0,035^{* * *}$ & $0,022^{*}$ & $0,029 * * *$ \\
\hline & $(0,037)$ & $(0,039)$ & $(0,018)$ & $(0,013)$ & $(0,013)$ & $(0,011)$ \\
\hline \multicolumn{7}{|l|}{ Sosial Ekonomi } \\
\hline \multirow[t]{2}{*}{ LITRATE } & 0,127 & $-0,027$ & 0,147 & 0,139 & $-0,434^{* * *}$ & \\
\hline & $(0,203)$ & $(0,916)$ & $(0,194)$ & $(0,109)$ & $(0,101)$ & \\
\hline \multirow[t]{2}{*}{ WEALTH } & 0,0004 & 0,001 & - & $0,001^{* * *}$ & $-0,002^{* * *}$ & $0,001^{* * *}$ \\
\hline & $(0,000)$ & $(0,002)$ & & $(0,000)$ & $(0,000)$ & $(0,000)$ \\
\hline \multirow[t]{2}{*}{ POVRATE } & $0,582^{* * *}$ & 1,964 & $0,509^{* * *}$ & $0,474^{* * *}$ & 0,758 & $0,423^{* * *}$ \\
\hline & $(0,155)$ & $(1,282)$ & $(0,143)$ & $(0,111)$ & $(0,883)$ & $(0,093)$ \\
\hline \multicolumn{7}{|l|}{ Karakteristik Daerah } \\
\hline \multirow[t]{2}{*}{ PROLIF } & $-1,374$ & - & $-1,210$ & $-10,990 * * *$ & - & $-10,945^{* * *}$ \\
\hline & $(1,877)$ & & $(1,728)$ & $(1,741)$ & & $(1,497)$ \\
\hline \multirow[t]{2}{*}{ JAVN } & $-4,420^{*}$ & - & $-4,348^{*}$ & $11,655^{* * *}$ & - & $10,824^{* * *}$ \\
\hline & $(2,398)$ & & $(2,438)$ & $(2,910)$ & & $(2,950)$ \\
\hline \multirow[t]{2}{*}{ C } & $-1,688$ & $-17,013$ & $-0,213$ & 18,003 & 77,966 & 32,223 \\
\hline & $(19,727)$ & $(95,273)$ & $(18,916)$ & $(11,178)$ & $(23,406)$ & $(2,304)$ \\
\hline \multicolumn{7}{|l|}{ Weighted Statistic } \\
\hline R-squared & 0,250 & 0,405 & 0,238 & 0,389 & 0,786 & 0,420 \\
\hline Adjusted R-squared & 0,205 & 0,217 & 0,203 & 0,352 & 0,719 & 0,393 \\
\hline $\mathrm{S}, \mathrm{E}$, of regression & 15,787 & 15,722 & 15,853 & 14,407 & 8,661 & 14,466 \\
\hline Sum squared resid & & 29,908 & & & 9,077 & \\
\hline Log likelihood & & $-645,49$ & & & $-550,10$ & \\
\hline F-statistic & 5,565 & 2,163 & 6,770 & 10,601 & 11,697 & 15,704 \\
\hline Prob(F-statistic) & 0,000 & 0,001 & 0,000 & 0,000 & 0,000 & 0,000 \\
\hline
\end{tabular}


SMP, tingkat pendidikan kepala keluarga terbukti secara signifikan mempengaruhi disparitas akses pendidikan tingkat SMP. Dalam banyak kasus di beberapa daerah, banyak keluarga yang memprioritaskan pendidikan putra putrinya hingga ke tingkat pendidikan SD namun kemudian setelah lulus beberapa diantaranya terpaksa harus bekerja baik karena alasan ekonomi maupun alasan lainnya.

Lain halnya dengan variabel berikutnya yaitu tingkat kemiskinan. Hasil estimasi memperlihatkan bahwa kemiskinan berdampak signifikan dan positif terhadap disparitas akses pendidikan baik di tingkat pendidikan SD maupun menengah. Dengan kata lain semakin tinggi tingkat kemiskinan suatu provinsi, semakin tinggi pula disparitas akses pendidikan di dalamnya. Kemiskinan dari dimensi ekonomi sangat erat kaitannya dengan kemampuan penduduk untuk mengakses atau membiayai akses pendidikan. Beberapa program seperti Bantuan Operasional Sekolah (BOS) yang kemudian banyak disalahartikan sebagai biaya sekolah gratis menjadi salah satu bukti bahwa tingkat kemiskinan masih menjadi faktor yang berpengaruh terhadap akses pendidikan masyarakat.

Faktor karakteristik daerah juga terbukti mempengaruhi disparitas akses pendidikan dasar. Untuk daerah-daerah pemekaran, terbukti memiliki disparitas akses pendidikan dasar yang lebih tinggi dibandingkan daerah bukan pemekaran utamanya untuk tingkat pendidikan SMP.

Selain itu, hasil estimasi 6 model terpilih menunjukkan koefisien Dummy Jawa- Luar Jawa yang signifikan terhadap disparitas akses pendidikan baik pendidikan SD maupun menengah. Yang menarik terdapat perbedaan koefisien antara pendidikan SD dan SMP. Pada pendidikan SD, koefisien regresinya bertanda negatif yang berarti pula bahwa Provinsi-provinsi di wilayah Jawa memiliki disparitas akses pendidikan SD yang lebih baik dibanding di luar Jawa. Sementara untuk akses pendidikan SMP justru sebaliknya. Dalam hal ini berarti bahwa provinsi-provinsi yang berada di Jawa memiliki disparitas akses pendidikan SMP yang lebih tinggi dibandingkan dengan di luar Jawa. Terdapat beberapa hal yang memungkinkan terjadinya "asymmetric condition" ini. Kemungkinan pertama adalah perbedaan struktur dan distribusi penduduk di wilayah Jawa dan Luar Jawa. Yang kedua, jika melihat perkembangan rata-rata Disparitas APK di wilayah Jawa dengan Luar Jawa memang dalam periode studi (2005-2009) umumnya disparitas di wilayah Jawa lebih tinggi dibandingkan dengan di Luar Jawa walaupun dengan kecenderungan yang menurun cukup tajam. Sementara untuk wilayah luar jawa relatif tidak banyak perubahan selama periode studi.

Selain beberapa hal di atas, bahwa dari hasil estimasi panel dengan pendekatan fixedeffect diperoleh juga gambaran beberapa provinsi yang relatif memiliki upaya-upaya untuk menekan disparitas akses pendidikan baik di tingkat pendidikan SD maupun pendidikan SMP relatif lebih baik dibandingkan provinsi lainnya. Hal ini tampak dari cross-section fixed effect untuk masing-masing provinsi yang ditandai dengan arah negatif dari masing-masing koefisien fixed effect yang ada.

\section{Hasil dan Pembahasan}

\section{Perkembangan Disparitas Akses Pendidik- an SD dan SMP}

Seperti telah disampaikan di atas sepanjang 2004-2009 disparitas akses pendidikan dasar semakin menurun. Untuk tingkat SD, disparitas APK menurun dari 2,49 persen di tahun 2004 menjadi 2,40 persen di tahun 2009. Sementara untuk SMP, APK menurun dari 25,1 persen di tahun 2004 menjadi 23 persen di tahun 2009. Hal ini masih kurang optimal jika melihat capaian dari penurunan APK SD dan SMP yang ditargetkan. Disparitas APK SD untuk tahun 2009 saja ditargetkan sebesar 2,30 persen dan 19 persen untuk disparitas APK SMP. Hal ini mencer- 


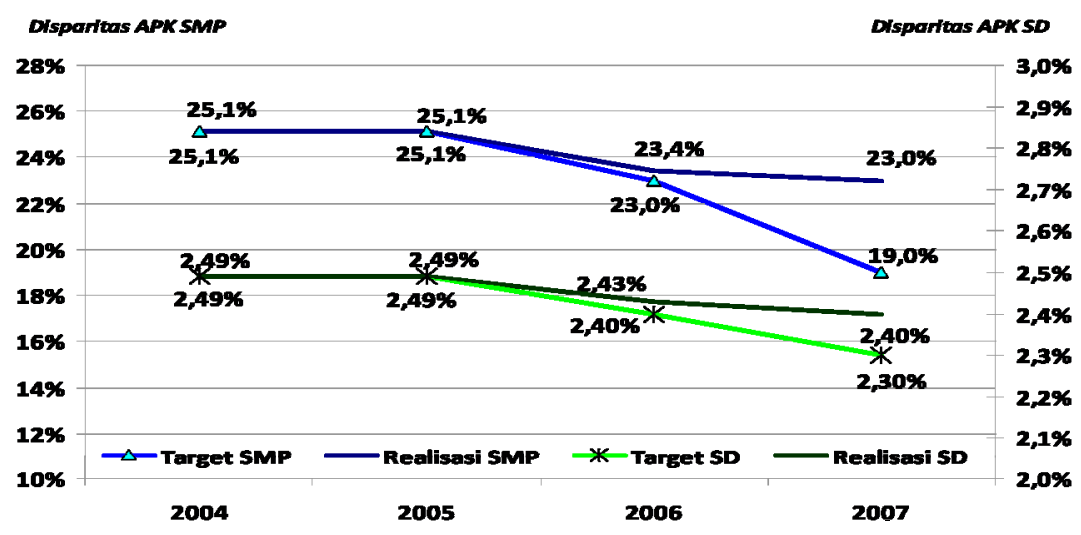

Sumber: Laporan Akuntabilitas Kinerja Pemerintah, Depdiknas, 2007, diolah

Gambar 1. Target dan Realisasi Disparitas APK Sekolah Dasar dan SMP

minkan bahwa pemerataan akses pendidikan dasar di Indonesia telah berlangsung dengan baik namun masih terdapat beberapa hal yang perlu dilakukan untuk mengoptimalkan pemerataan akses dasar dimaksud. Khususnya tingkat kabupaten/ kota, dimana disparitas yang cukup besar itu mengindikasikan lebih pentingnya prioritas pembangunan infrastruktur secara umum di kabupaten daripada di kota. Tujuannya agar pelayanan pendidikan di kawasan pedesaan lebih mudah dijangkau (Media Indonesia Online, 2008).

Hal lain yang dapat dikemukan adalah capaian penurunan disparitas APK SD dan SMP untuk tiap-tiap provinsi yang ada di Indonesia. Gambar 2 menjelaskan bahwa beberapa provinsi dapat menurunkan disparitas APK SD dan SMP nya di bawah tingkat nasional. Walaupun demikian, terdapat pula beberapa provinsi yang memiliki APK SD dan SMP di atas tingkat disparitas APK SD
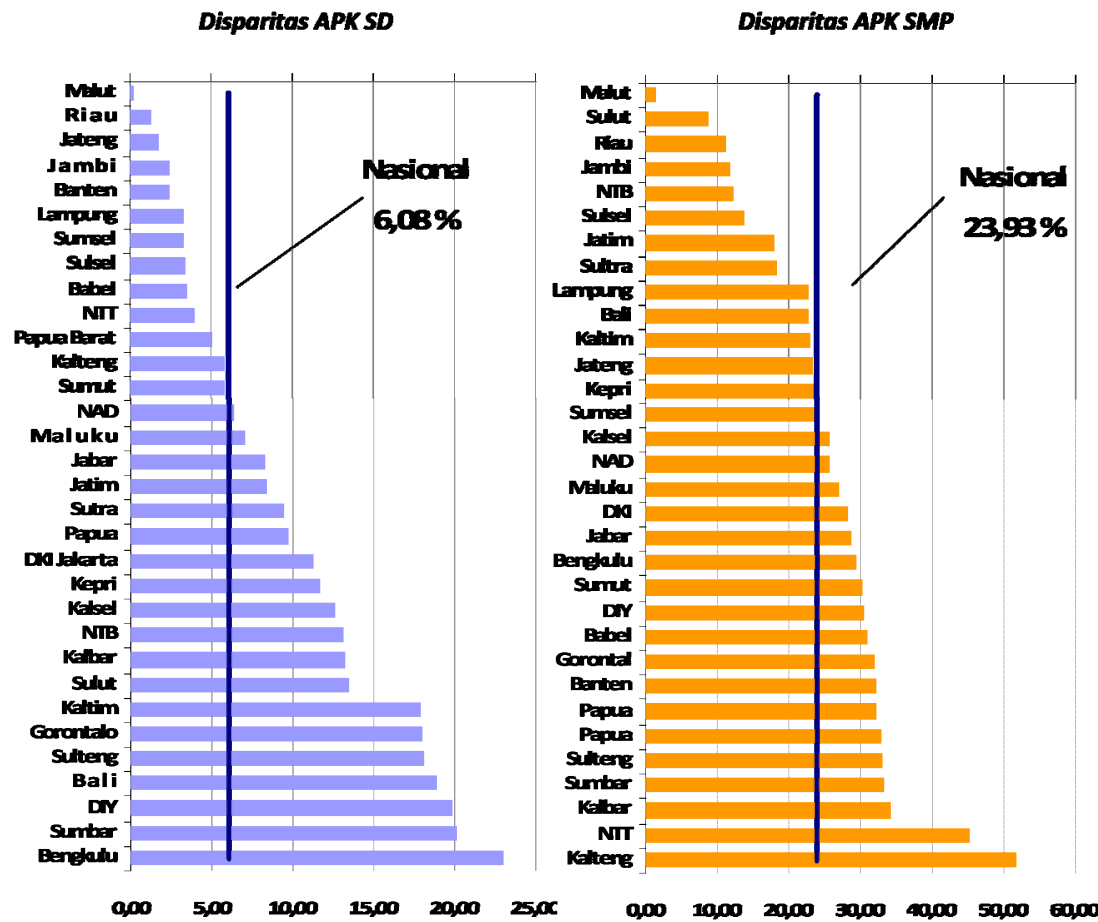

Sumber: Kementerian Pendidikan Nasional, diolah

Gambar 2. Disparitas APK SD dan SMP Menurut Provinsi 2008 
dan SMP nasional. Provinsi-provinsi seperti Riau, Jawa Tengah, Sulawesi Selatan, dan Sumatera Selatan memiliki disparitas yang relatif lebih baik dibandingkan daerah lain. Dengan kata lain provinsi-provinsi tersebut relatif lebih baik dalam hal pemerataan akses pendidikan tingkat dasar.

\section{Perkembangan Instrumen Desentralisasi Fiskal dan Indikator Sosial Ekonomi}

Perkembangan instrumen desentralisasi fiskal yang ada juga patut menjadi perhatian. Beberapa instrumen fiskal yang ada baik yang terkait langsung dengan otonomi daerah dan desentralisasi fiskal maupun instrumen keuangan daerah yang mempengaruhi pelaksanaan pembangunan di daerah. Desentralisasi fiskal akan berdampak mengurangi ketimpangan pendapatan antardaerah terutama daerah-daerah di Pulau Jawa dengan Luar Pulau Jawa (Waluyu, 2008).

Dalam Tabel 2 dapat dilihat bahwa secara umum instrumen-instrumen yang ada mengalami peningkatan yang cukup signifikan sepanjang tahun 2005-2009. Misalnya saja DAU yang meningkat lebih dari dua kali lipat sepanjang 2005-2009. Bahkan untuk DAK Pendidikan meningkat hampir tiga kali lipat sepanjang 2005-2009. Hasil penelitian dari tim peneliti Semeru (Usman, $d k k, 2008$ ) merekomendasikan sebuah paradigma baru berupa pendesentralisasian kepada pemerintah provinsi kewenangan pengalokasian, pengkoordinasian, pengawasan pelaksanaan atas penggunaan DAK oleh pemerintah kabupaten/kota. Adapun menurut Nainggolan (2010) kriteria kelayakan kabupaten/kota

Di sisi lain, perkembangan beberapa indikator sosial ekonomi juga menunjukkan perkembangan yang cukup positif. Hal ini juga berdampak pada keadaan iklim usaha yang kondusif terhadap perekonomian daerah dalam bentuk, a) percepatan pertumbuhan ekonomi daerah; b) penurunan tingkat pengangguran; c) peningkatan upah tenaga kerja; d) pengentasan ke miskinan; dan e) peningkatan pendapatan asli daerah (Isdijoso dan Tri, 2002). Perkembangan PRDB per kapita yang meningkat, tingkat kemiskinan menurun serta tingkat melek huruf yang meningkat juga terlihat pada Tabel 3. Kesemuanya diharapkan memberikan dampak yang positif terhadap penurunan disparitas akses pendidikan dasar di Indonesia.

\section{Simpulan}

Hasil penelitian memperlihatkan bahwa instrumen fiskal yang bersifat khusus (DAK) memiliki dampak yang lebih signifikan dibandingkan instrumen yang bersifat umum. Selain itu juga terbukti bahwa DAK pendidikan ini memberikan dampak yang relatif lebih nyata untuk menurunkan disparitas akses pendidikan di tingkat SMP. Sementara itu, PAD terbukti pula berdampak negatif terhadap disparitas akses pendidikan tingkat SD. Hal ini berkaitan dengan disparitas PAD itu sendiri antara kabupaten/kota.

Tabel 2. Perkembangan Instrumen Desentralisasi Fiskal (Rupiah Per Kapita)

\begin{tabular}{lrrrrr}
\hline \multicolumn{1}{c}{ Instrumen Fiskal } & $\mathbf{2 0 0 5}$ & $\mathbf{2 0 0 6}$ & \multicolumn{1}{c}{$\mathbf{2 0 0 7}$} & \multicolumn{1}{c}{$\mathbf{2 0 0 8}$} & $\mathbf{2 0 0 9}$ \\
\hline DAU & 600.416 & 988.967 & 1.127 .179 & 1.085 .564 & 1.380 .415 \\
DAK Pendidikan & 13.579 & 26.042 & 45.243 & 59.557 & 69.247 \\
DAK Non Pendidikan & 33.161 & 86.015 & 119.888 & 165.222 & 158.809 \\
PAD & 57.530 & 80.604 & 97.635 & 161.890 & 119.924 \\
\hline
\end{tabular}

Sumber: Kementerian Keuangan dan BPS, diolah.

Tabel 3. Perkembangan Indikator Sosial Ekonomi

\begin{tabular}{llllcc}
\hline \multicolumn{1}{c}{$\begin{array}{c}\text { Indikator } \\
\text { Sosial Ekonomi }\end{array}$} & $\mathbf{2 0 0 5}$ & $\mathbf{2 0 0 6}$ & $\mathbf{2 0 0 7}$ & $\mathbf{2 0 0 8}$ & $\mathbf{2 0 0 9}$ \\
\hline Rata-Rata PDRB (Rp Juta per Kapita) & 7,10 & 7,24 & 7,58 & 7,95 & 8,20 \\
Tingkat Kemiskinan (\%) & $17,92 \%$ & $18,83 \%$ & $17,64 \%$ & $16,24 \%$ & $15,13 \%$ \\
Tingkat Melek Huruf & 88,8 & 91,7 & 92,1 & 92,7 & 93,0 \\
\hline
\end{tabular}

Sumber: BPS, diolah. 
Sementara itu, untuk akses pendidikan tingkat SMP sangat sulit untuk membedakan akses pendidikan antar kabupaten/kota secara riil mengingat akses pendidikan tingkat SMP lebih bersifat lintasdaerah ketimbang tingkat SD.

Dipandang dari sisi kondisi sosial ekonomi masyarakat terungkap paling tidak dua hal yang mendasar. Pertama bahwa tingkat pendidikan masyarakat tidak membedakan akses terhadap pendidikan pada tingkat SD namun cukup signifikan pada tingkat SMP. Dengan kata lain, dorongan kepala rumah tangga untuk pendidikan anak-anaknya pada tingkat SD cukup besar, namun belum diikuti oleh akses pendidikan pada tingkat menengah. Tekanan ekonomi sangat mungkin menjadi penyebabnya. Hal ini terbukti dari cukup signifikannya dampak tingkat kemiskinan di suatu daerah terhadap disparitas akses pendidikan dasar.

Selain itu, faktor karakteristik daerah juga terbukti mempengaruhi disparitas akses pendidikan dasar. Untuk daerah-daerah pemekaran, terbukti memiliki disparitas akses pendidikan dasar yang lebih tinggi dibandingkan daerah bukan pemekaran utamanya untuk tingkat pendidikan SMP. Sementara itu, untuk daerah Jawa dan luar Jawa memiliki arah yang berbeda untuk tingkat SD dan SMP. Untuk tingkat SD, daerah Jawa menunjukkan disparitas yang lebih rendah dibandingkan daerah luar Jawa. Untuk tingkat SMP, justru daerah Jawa menunjukkan disparitas yang lebih besar dibandingkan daerah luar Jawa.

Desentralisasi fiskal ditujukan untuk mendukung berlangsungnya otonomi daerah yang tidak saja merupakan kewenangan yang lebih besar bagi pemerintah daerah untuk melaksanakan pembangunan di daerahnya namun juga pemerataan pembangunan antar daerah. Dalam hal pembangunan pendidikan nasional, desentralisasi fiskal melalui berbagai instrumen dan kebijakannya diharapkan mampu untuk mendukung dan mendorong pemerataan pelayanan pendidikan, khususnya pendidikan dasar yang menjadi hak setiap warganegara. Instrumen fiskal yang bersifat khusus seperti DAK pendidikan hendaknya dapat lebih dioptimalkan lagi sementara instrumen yang bersifat umum seperti DAU diharapkan dapat memberikan dampak yang nyata untuk mengurangi disparitas akses pendidikan dasar dari sisi kemampuan dan kemauan masyarakat. Hal yang sama juga bagi DAK non Pendidikan yang lebih diarahkan pada pembangunan infrastuktur di berbagai bidang yang diharapkan dapat mendorong kemampuan ekonomi masyarakat dan pada gilirannya kemampuan dan kemauan masyarakat untuk mengakses layanan pendidikan dasar.

Ke depan kebijakan-kebijakan desentralisasi fiskal dan pembangunan pendidikan khususnya pendidikan dasar diharapkan dapat lebih memperhatikan pemerataan pembangunan baik untuk daerah-daerah baru hasil pemekaran maupun pemerataan akses pendidikan untuk wilayah Jawa dan luar jawa sehingga pemerataan pelayanan pendidikan dapat berjalan lebih baik lagi. Upaya-upaya untuk pengentasan kemiskinan dan peningkatan kemampuan ekonomi masyarakat juga penting artinya untuk terus dilakukan untuk dapat meningkatkan pemerataan pembangunan di berbagai bidang salah satunya dalam bidang pendidikan dasar. Selain itu, untuk penelitian-penelitian selanjutnya dapat pula untuk mempertimbangkan disparitas dari faktor-faktor terkait dalam mengkaji disparitas akses pendidikan dasar di Indonesia atau juga turut mempertimbangkan faktor-faktor input dalam pendidikan seperti guru, ruang kelas, fasilitas sekolah dan lainnya dalam mengkaji lebih jauh dampaknya terhadap disparitas akses pendidikan dasar di Indonesia.

\section{Daftar Pustaka}

Isdijoso, Brhamantio dan Tri Wibowo. 2002. Analisis Kebijakan Fiskal Pada Era Otonomi Daerah (Studi Kasus: Sektor Pendidikan di Surakarta).

http://fiskal. depkeu.go.id/ webbkf/ 
kajian\%5CBramtri-1.pdf. Diakses tanggal 18 November 2010.

Media Indonesia Online. 2008. Pendidikan Yang Tidak Pernah Tuntas. http:// meekfoundation.org/index.php?act $=$ art icles\&type $=h \& d o=v i e w \& i d=279$. Diakses tanggal 18 November 2010.

Nainggolan, Pahala. 2010. Menggugat Desentralisasi Fiskal Pendidikan Dasar. http:/ / pahalanainggolan.wordpress.co $\mathrm{m} / 2010 / 10 / 06 m e n g g u g a t-$ desentralisasi-pendidikan-dasar. Diakses tanggal 18 November 2010.

Usman, Syaikhu., M. Sulton Mawardi, Adri Poesoro, Asep Suryahadi. 2008. Mekanisme dan Penggunaan Dana Alokasi Khusus. Laporan Hasil Penelitian Lembaga Penelitian Semeru. http:// www.semeru.or.id/report/research/da k/dak_ind.pdf. Diakses tanggal 18 November 2010.

Waluyu, Joko. 2008. Dampak Desentralisasi Fiskal Terhadap Pertumbuhan Ekonomi dan Ketimpangan Pendapatan Antar Daerah di Indonesia Tahun 2001-2005. http://mrwaluyu.blogspot.com/2008/0 2.dampak-desentralisasi-fiskal.html. Diakses tanggal 18 November 2010.

Baltagi, Badi H. 2001. Econometric Analysis of Panel Data, England: John Wiley \& Sons Ltd.

Boissiere, Maurice. 2004. Determinants of Primary Education Outcomes in Developing Countries, OED Working Papers, World Bank.
Brodjonegoro, Bambang. 2003. Three Years of Fiscal Decentralization in Indonesia: It's Impact on Regional Economic Development and Fiscal Sustainability. Jakarta: Department of Economics, University of Indonesia.

Elmi, Bachrul. 2002. Kebijakan Desentralisasi Fiskal Kaitannya Dengan Hutang Luar Negeri Pemerintah Daerah Otonom. Kajian Ekonomi dan Keuangan. Vol. 6, No. 4, Desember.

Faguet, J. Paul and Fabio Sanchez. 2006. Decentralization's effects on educational outcomes in Bolivia and Colombia, London School of Economics and Political Science.

Glewwe, Paul. 2002. Schools and skills in Developing Countries: Education Policies and Socioeconomicc Outcomes. Journal of Economic Literature 40:436-482.

Greene, William H. 1997. Econometric Analysis, third edition, London: Prentice Hall.

Hsiao, Cheng. 2003. Analysis of Panel Data: Second Edition, Cambridge University Press.

Kementerian Pendidikan Nasional. 2009. Ikhtisar Data Pendidikan Nasional.

Murillo, M.V., M. Tommasi, L.Ronconi, dan J.Sanguinetti. 2002. The economic Effects of unions in Latin America: Teachers unions and education in Argentina. Research network. Working Paper \#R-463, Inter-American Development Bank. 